\title{
SPINAL CORD INJURY AND MALE INFERTILITY: A REVIEW
}

\author{
TRAUMATISMO RAQUIMEDULAR E INFERTILIDADE MASCULINA: REVISÃO
}

\author{
LESIÓN DE LA MÉDULA ESPINAL E INFERTILIDAD MASCULINA: UNA REVISION
}

Asdrubal Falavigna1', Guilherme Finger², Olívia Egger de Souza², Fabio Firmbach Pasoualotto³

\begin{abstract}
Spinal cord injuries remain an important factor of morbimortality in current society, involving mainly males from adolescence to adulthood. Among the sequelae caused by spinal cord injuries, the impairment of the sexual system is highly relevant since it affects the quality of sexual life and paternity. Infertility is secondary to multiple events such as erectile dysfunction, anejaculation, seminal biochemical modification and morphology of spermatozoa. Current therapies for the infertile spinal cord injured patient focus on the ejaculation stimulus followed by intrauterine insemination, leaving seminal low quality as the major factor of infertility in these patients. In this scenario, therapy with hyperbaric oxygenation, which is still being studied, represents an alternative treatment since it focuses on the central nervous system injured by the trauma and the testicular tissue in order to decrease spinal damage and to preserve the physiological regulation of the urogenital system as a form of avoiding infertility.
\end{abstract}

Keywords: Spinal cord injuries, Infertility; Hyperbaric oxygenation; Erectile dysfunction; Trauma to the nervous system.

\section{RESUMO}

O trauma raquimedular (TRM) é uma importante causa de morbimortalidade na sociedade atual, principalmente por acometer adultos jovens. Dentre as diversas sequelas decorrentes da lesão medular encontram-se as alterações na qualidade de vida sexual e na paternidade. A infertilidade decorre de diversas alterações como: disfunção erétil, anejaculação, alterações bioquímicas no sêmen e estruturais nos espermatozoides. As terapias para a infertilidade pós-TRM, em geral, objetivam o estímulo à ejaculação e posterior inseminação, sendo a baixa qualidade do sêmen o fator determinante para infertilidade. A terapia hiperbárica representa uma possibilidade de atuar diretamente no tecido lesado, seja ele medular ou testicular, diminuindo o dano.

Descritores: Traumatismos da coluna vertebral; Infertilidade; Oxigenação hiperbárica; Disfunção erétil; Traumatismo do sistema nervoso.

\section{RESUMEN}

La lesión de la médula espinal sigue siendo una causa importante de morbilidad y mortalidad en la sociedad actual, que afecta principalmente a hombres en la adolescencia a la edad adulta. Entre las varias secuelas resultantes de lesiones de la médula espinal, el deterioro del sistema sexual es de gran relevancia una vez que afectan la calidad de la vida sexual y la paternidad. La infertilidad es secundaria a varios eventos, tales como la disfunción eréctil, aneyaculación, modificación bioquímica seminal y la morfología de los espermatozoides. Los tratamientos para la infertilidad post-TRM, en general, tienen por objeto estimular la eyaculación seguida de inseminación in vitro, siendo la baja calidad seminal el factor determinante de la infertilidad de estos pacientes. En este escenario, la terapia con oxigenación hiperbárica, aún en estudio, representa un tratamiento alternativo ya que actúa sobre el sistema nervioso central lesionado por el trauma y sobre el tejido testicular para reducir el daño espinal y preservar la regulación fisiológica del sistema genital como una forma de evitar la infertilidad.

Descriptores: Traumatismos vertebrales; Infertilidad; Oxigenación hiperbárica; Disfunción eréctil, Traumatismos del sistema nervioso.

\section{INTRODUCTION}

Spinal Cord injury (SCI) has become a social epidemic of major proportions in the public health system ${ }^{1,2}$, since it is a frequent cause of severe incapacity and death after trauma. Traumatic lesions of the spinal cord occur more often in young males (80\%) $)^{3,4}$ aged 16 to $35^{2,5,6}$, and therefore it has a high financial impact ${ }^{7,8}$.

$\mathrm{SCl}$ is an incapacitating clinical condition with permanent and debilitating effects on the patient's quality of life, since $70 \%$ remain paraplegic and $30 \%$ remain tetraplegic. Besides, other body systems are affected, of which the endocrine and reproductive apparatus play an important role? .

When young males with $\mathrm{SCl}$ are analyzed, it is found that only $30 \%$ are married and also $30 \%$ have children at the time trauma occurs $^{5}$. After the $\mathrm{SCl}$, the possibility of having children depends on the spinal trauma severity (complete or incomplete) and its repercussion on the reproductive system. Among patients with no offspring with complete spinal lesions, only $10 \%$ will be able to achieve paternity with medical aid ${ }^{10,11}$. Under these circumstances, reproductive capacity is found to be of great relevance after $\mathrm{SCl}$, making sexual rehabilitation the main priority to be considered ${ }^{3,10}$.

The loss of encephalic control over the male reproductive apparatus determines an inability to have an erection and ejaculate, associated with worse seminal quality. Male sexual dysfunction occurs in $75 \%$ of patients with $\mathrm{SCl}^{12}$, contrasting with the general population in whom the prevalence of male sexual dysfunction is $7 \%{ }^{13}$. Although most men with spinal cord injury may have some sort of erection (reflexogenic, psycogenic or pharmacological), many can not ejaculate during sex. Besides, these patients have decreased quality and formation of the sperm, secondary to loss of autonomic regulation due to $\mathrm{SCl}$.

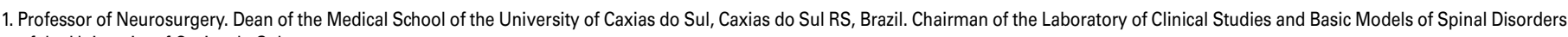
of the University of Caxias do Sul.

2. Medical Student, University of Caxias do Sul, Caxias do Sul, RS, Brazil. Scholar of the Laboratory of Clinical Studies and Basic Models of Spinal Disorders of the University of Caxias do Sul. 3. PhD in Urology of São Paulo University. Professor of Anatomy, Embriology and Urology of the University of Caxias do Sul.
}

This project was developed at the University of Caxias do Sul, Caxias do Sul, RS, Brazil. Address: Rua General Arcy da Rocha Nóbrega, 401/602 - Caxias do Sul, RS, Brazil. 95040-290. asdrubalmd@gmail.com 
The objective of this article is to review the factors involved in male sexual dysfunction after $\mathrm{SCl}$, also analyzing current treatment and potential therapeutic targets studied.

\section{Physiology of male sexual function}

Sexual function depends on the spinal cord reflexes and on the cortical control. Reflexogenic erections involve the parasympathetic autonomous nervous system and sacral spinal cord. However, psychogenical erection depends on adequate cerebral cortical functioning, including the limbic system, visual and hearing cortex, and the connections of these centers to the autonomic spinal cord centers ${ }^{14}$

The parasympathetic system sends efferent fibers from the second to the fourth sacral spinal cord segment, which performs synapses with the pelvic plexus using acetylcholine as the neurotransmitter. Acetylcholine promotes erection and stimulates a secretory response of the urethral and bulbourethral glands. Erection can also be mediated by nitric oxid, since it has a relaxing effect on arterial and arteriolar smooth muscles represented by vasodilatation ${ }^{14}$.

The sympathetic system has the reflexogenic center located in the spinal cord between the second thoracic segment (T2) and the second lumbar segment (L2), and is responsible for ejaculation during sex. The information leaves these spinal segments reaching the pelvic plexus by the hypogastric and pelvic nerves. The first synapse of the sympathetical system is cholinergic, while the second is mediated by norepinephrine ${ }^{5,15}$. Ejaculation is obtained by the contraction of the prostate and seminal vesicle, associated with constriction of the internal urethral sphincter.

Somatic stimulus is also important for penile erection, since it is important for sensibility and for bulbocavernosus and ischiocavernosus muscle contractions in the final stages of erection and ejaculation. Somatic nerves originate from the second to the fourth sacral spinal segment ${ }^{14}$.

\section{Infertility on the SCI patient}

After the primary mechanical lesion on the spinal cord, a cascade of events leads to secondary degeneration and death of the potentially viable neuronal tissue ${ }^{16-18}$. Among the components of the secondary lesion, hypoxia/ischemia is considered of utmost importance to spinal tissue injury, impairing the physiological medullar mechanism and its encephalic connections. Consequently, a motor and sensitive dysfunction develops on the somatic and visceral musculature, resulting in the high rates of sexual dysfunction and anejaculation $^{19}$.

The effects over sexual physiology depend on kind, level and intensity of trauma ${ }^{20}$. Patients with complete spinal cord lesion of the higher motor neuron are able to achieve reflex erections, but not intentional cortical erections. On the other hand, patients with incomplete higher motor neuron lesion can have reflex and psychogenic or intentional erections, although they are often not sufficient for intercourse.

Among patients with complete $\mathrm{SCl}$, ejaculation is obtained in $5 \%$ of males. Comparatively, erection is achieved in $90 \%$ and ejaculation in $70 \%$ of patients with incomplete $\mathrm{SCl}^{14,17}$. When patients with complete lesion of the lower motor neuron are analyzed, 25\% of males with $\mathrm{SCl}$ at the sacral level are able to have psychogenic erection and can ejaculate, but reflex erections are unusual ${ }^{14,20}$ (Table 1).

$\mathrm{SCl}$ patients exhibit hormonal alterations on thyroid, hypothalamic and gonadal glands. Serum concentration of thyroxine and triiodothyronine are low ${ }^{9,21}$. Abnormalities involving the diminishing levels of luteinizing and follicle stimulating hormone indicate alterations on the hypothalamic-pituitary-gonadal axis. The most accepted hypothesis for this condition is that the chronic post-traumatic stress of the post-traumatic state prevents pulsatile secretion of gonadotropins ${ }^{21}$. Lastly, serum testosterone levels diminish after $\mathrm{SCl}$, although it is not understood if this situation results from the neurologic insult or if it is secondary to physical and emotional stress triggered by the trauma ${ }^{9}$.
Table 1. Rates of erection and ejaculation according to the spinal cord injury severity.

\begin{tabular}{|c|c|c|c|}
\hline & Complete SCl* & Incomplete SCl* & References \\
\hline Psychogenic erection UMNº & $9 \%$ & $48-79 \%$ & $\begin{array}{c}\text { Monga, } 1999 . \\
\text { Linsenmeyer, } 1991 .\end{array}$ \\
\hline Reflexogenic erection UMNº & $95 \%$ & $90-93 \%$ & Monga, 1999. \\
\hline Psychogenic erection LMNª & $24-25 \%$ & - & $\begin{array}{l}\text { Monga, } 1999 . \\
\text { Ricciardi, } 2007 .\end{array}$ \\
\hline Reflexogenic erection $\mathrm{LMN}^{\mathrm{a}}$ & $12 \%$ & - & Monga, 1999. \\
\hline Ejaculation & $5 \%$ & $70 \%$ & $\begin{array}{c}\text { Monga, } 1999 . \\
\text { Linsenmeyer, } 1991 .\end{array}$ \\
\hline
\end{tabular}

\section{Causes of infertility after spinal cord injury}

According to current medical literature, fertility impairment in patients with $\mathrm{SCl}$ is the result of the neuronal damage represented by erectile dysfunction and anejaculation associated with testicular alterations, evidenced by spermatogenesis deficit5,20,22,23 (Flowchart 1). Moreover, contributing factors in these patients include repetitive urinary tract infection, scrotal loss of thermoregulation, medicines, retrograde ejaculation, and changes in seminal fluid ${ }^{3}$ (Table 2).

It is believed that autonomic alterations trigger the loss of homeostasis in the central nervous system (CNS). SCI with complete medular lesion prevents cortical stimulus from reaching the spinal cord at the appropriate level. Besides, the high leucoespermia and DNA fragmentation of sperm are characteristic findings in this population, suggesting the presence of constant inflammatory process, producing cytotoxic factors in semen such as reactive oxygen species (ROS) $)^{22-24}$.

Physiological and controlled production of ROS are of utmost importance for sperm function and reactions, such as tyrosin kinase phosphorylation, hyperactivation, capacitation and acrosome reaction. The control of ROS production is also performed by the synthesis of antioxidant substances ${ }^{25}$. Superoxide dismutase and catalase are important antioxidant enzymes extinguishing, respectively, the excess of free radicals superoxide and hydrogen peroxide ${ }^{26}$. The seminal fluid also has other enzymatic antioxidant substances such

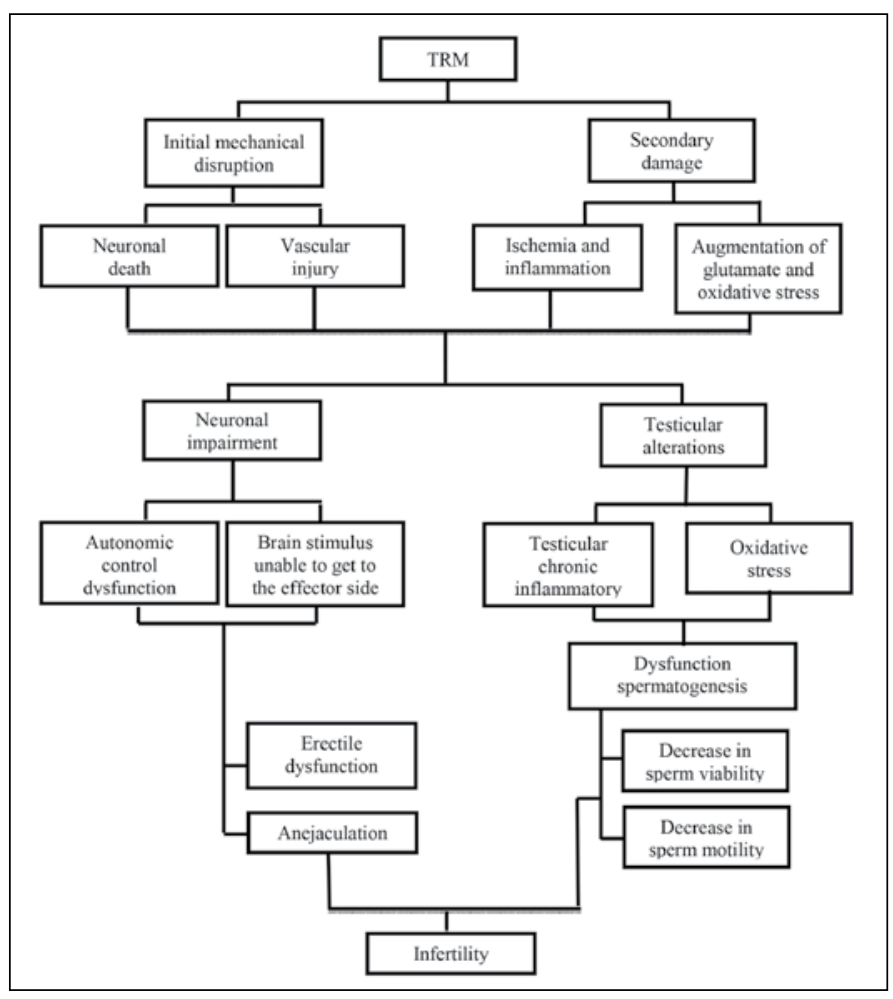

Flowchart 1. Events after spinal cord injury that lead to infertility. 
Table 2. Causes of anejaculation, erection and spermatogenesis dysfunction after spinal cord injury.

\begin{tabular}{|c|c|c|}
\hline Features & Causes & References \\
\hline $\begin{array}{l}\text { Erectile dysfunction } \\
\text { and anejaculation }\end{array}$ & $\begin{array}{c}\text { Neurologic injury that causes autonomic control } \\
\text { dysfunction } \\
\text { Brain stimulus unable to get to the effector side }\end{array}$ & $\begin{array}{c}\text { Iremashvili, } 2010 . \\
\text { Ricciardi, } 2007 . \\
\text { Kathiresan, } 2011 . \\
\text { Brackett, } 2010 .\end{array}$ \\
\hline $\begin{array}{c}\text { Dysfunction } \\
\text { spermatogenesis }\end{array}$ & $\begin{array}{c}\text { Testicular chronic inflammatory process } \\
\text { Detectable levels of reactive oxygen species } \\
\text { Oxidative stress } \\
\text { Increase in midpiece morphologic defects. } \\
\text { Decrease in energetic cellular production } \\
\text { DNA fragmentation }\end{array}$ & $\begin{array}{c}\text { Kathiresan, } 2011 . \\
\text { Brackett, } 2010 . \\
\text { Ibrahim, } 2009 . \\
\text { Pasqualotto, } 2008 . \\
\text { Moustafa, } 2004 . \\
\text { Agarwal, } 2003 . \\
\text { Griveau, } 1995 .\end{array}$ \\
\hline Other factors & $\begin{array}{l}\text { Retrograde ejaculation } \\
\text { Loss of scrotal thermoregulation } \\
\text { Drugs } \\
\text { Recurrent infections of the genitourinary tract } \\
\text { Changes in seminal constituents }\end{array}$ & Brackett, 1998. \\
\hline
\end{tabular}

as glutathione peroxidase, and a variety of non-enzymatic antioxidants such as ascorbic acid, $\alpha$-tocopherol, pyruvate and carnitine ${ }^{26}$.

However, when ROS levels are greater than the antioxidant system of seminal fluid, a reaction known as oxidative stress (OS) occurs $^{27}$. The OS promotes fatty acid degradation by ROS, in a process called lipid peroxidation ${ }^{28}$. Sperm are vulnerable to lipid peroxidation because they contain polyunsaturated fatty acids on cell membrane, substances that maintain fluidity for membrane fusion during fertilization.

There are two sources of the ROS found in seminal fluid: leucocytes and immature or defective sperm. Leucocytes, especially neutrophils and macrophages, are considered the primary source while the uncontrolled production of ROS by sperm depends on defective cell development, represented by retention of cytoplasmic organelles ${ }^{25,26}$

OS diminishes sperm motility and viability, increasing the prevalence of morphological abnormalities, all factors that impair sperm maturation and acrosome reaction ${ }^{27}$. Motility impairment is secondary to the destabilization and reduction of the cell control over the membrane selective permeable property, associated with alteration of the mitochondrial potential membrane. A mitochondrial dysfunction damages the cell functioning, evidenced by the lower cellular energy production ${ }^{29-31}$.

The production and amount of ROS are increased in infertile patients. When an analysis was performed to find out whether the concentration of ROS in infertile SCI patients was higher than in infertile patients for other reasons except SCl, studies showed discordant results. Results from a study conducted by Brackett ${ }^{32}$, showed no difference in ROS seminal concentration in infertile patients with $\mathrm{SCl}$ compared with infertile patients with no history of SCl. However, Padron et. al. ${ }^{33}$ found that the concentration of ROS is substantially higher in $\mathrm{SCl}$ patients.

Different forms of sperm DNA damage are caused by ROS, such as intersection of chromatin, chromosome deletion and oxidation $^{27}$. OS also promotes DNA nuclear fragmentation ${ }^{34}$, which impairs fertilization, genetic information passage and the correct embryological development ${ }^{35-37}$.

Although a few patients, especially those with incomplete spinal lesion, are able to achieve psychogenic or reflex erection, most of them can not ejaculate during intercourse ${ }^{3}$. Besides, even in those patients that have erection and ejaculation, the infertility index is elevated because semen quality is poor. It is believed that low seminal quality is a result of: stasis of prostatic fluid, testicular hyperthermia, abnormal testicular histology and sperm contact with urine or sperm antibodies ${ }^{23}$. These events will result in a decreased sperm count, progressive impairment of mobility and viability, and an increasing percentage of morphological spermatozoa alterations, such as the presence of two heads or abnormal tails ${ }^{32}$.

According to Iremashvili et al, there is effective treatment for erectile and ejaculation dysfunction, which makes sperm quality the major factor in the prospect of fatherhood for these patients ${ }^{4}$.

\section{Infertility therapy}

Most men with $\mathrm{SCI}$ requires medical treatment in order to achieve fatherhood ${ }^{22}$. The type of intervention depends on the patient's capacity of erection and on the seminal sperm status (Table 3).

Table 3. Treatment for erectile dysfunction, anejaculation and sperm viability.

\begin{tabular}{|c|c|c|c|}
\hline Dysfunction & Treatment options & Action mechanism & References \\
\hline $\begin{array}{c}\text { Erectile } \\
\text { Dysfunction }\end{array}$ & $\begin{array}{c}\text { Pills } \\
\text { Injection } \\
\text { Topical medication and } \\
\text { intraurethral prostaglandin } \\
\text { suppositories } \\
\text { Prosthesis }\end{array}$ & $\begin{array}{l}\text { Vasodilatation } \\
\text { Vasodilatation } \\
\text { Vasodilatation } \\
\text { Penile prosthesis }\end{array}$ & $\begin{array}{l}\text { Monga, } 1999 . \\
\text { Maddox , } 2011 .\end{array}$ \\
\hline $\begin{array}{l}\text { Ejaculation } \\
\text { Dysfunction }\end{array}$ & $\begin{array}{c}\text { Electroejaculation } \\
\text { External vibratory stimulation } \\
\text { Testicular microsurgery }\end{array}$ & $\begin{array}{c}\text { Induce ejaculation } \\
\text { Induce ejaculation } \\
\text { Sperm collection from } \\
\text { testicles. }\end{array}$ & $\begin{array}{c}\text { Iremashvili, } 2010 . \\
\text { Kathiresan, } 2011 . \\
\text { Maddox, } 2011 . \\
\text { Elliott, } 2000 .\end{array}$ \\
\hline Sperm viability & Hyperbaric oxygen therapy & $\begin{array}{c}\text { Decrease reactive } \\
\text { oxygen species } \\
\text { production }\end{array}$ & $\begin{array}{c}\text { Hillard, } 2007 . \\
\text { Falavigna, } 2009 . \\
\text { Ibrahim2009. } \\
\text { Brackett, } 2010 . \\
\text { Kathiresan, } 2011 .\end{array}$ \\
\hline $\begin{array}{l}\text { Sperm } \\
\text { quality }\end{array}$ & Artificial insemination & $\begin{array}{l}\text { Introduction of the } \\
\text { sperm in the ovule }\end{array}$ & Iremashvili, 2010 \\
\hline
\end{tabular}

\section{Hyperbaric oxigenation therapy}

In the scenario described above, it becomes relevant to research the effects of hyperbaric oxygenation therapy not only as a treatment for $\mathrm{SCl}$, but also to evaluate the influence over the physiological mechanisms involved in male fertility, such as the testicular inflammatory process that creates cytotoxic seminal factors $(\mathrm{ROS})^{22-24}$.

The healing process of the tissues damaged by trauma is divided into three phases: inflammatory, proliferative and remodeling. It is important to note that oxygen is an indispensable component of the repairing process ${ }^{16}$.

The action mechanism of the hyperbaric oxigenation theraphy is to increase the oxygen supply in the injured tissues, since the higher oxygen tension promotes collagen synthesis, angiogenesis and epithelization ${ }^{16,38}$.

\section{Treatment of sexual dysfunction}

For patients unable to achieve an effective erection for intercourse, defined erectile dysfunction, there are different therapies and products such as pills, injections, tablets and implants. Vasodilator drugs such as Viagra ${ }^{\circledR}$, Cialis ${ }^{\circledR}$ and Levitra ${ }^{\circledR}$ significantly improve sexual life and satisfaction of the patients with SCI between T6 and L5. The injection of papaverina or alprostadil in the lateral penis region promotes a vasodilatation and, consequently, an effective erection for almost 2 hours. The use of alprostadil tablets introduced in the urethra of the patient, in order to be absorved by the mucosa, results in a relaxation of the penile vessels with consequent blood filling. A penile prosthesis is a therapeutic option for erectile dysfunction, requiring the implantation of a synthetic material inside the cavernous body of the penis ${ }^{39}$.

\section{Management of ejaculatory dysfunction}

There are two current therapies to obtain semen in patients with SCl: electroejaculation by transrectal stimulus and vibro-stimulation over the glans $s^{5,23,29}$. Therapeutic algorithms that guide treatment of anejaculatory patients recommend a penile vibratory stimulus as the first choice therapy, followed by rectal stimulus ${ }^{22,23}$. The preference for electroejaculation is due to the possibility that this method can be performed at home, differently from the transrectal stimulus, which requires 
a specialized clinic to be accomplished, since the method involves implantation of an electric probe in the rectum. In cases in which sperm is not obtained either by glans or by rectal stimulus, it is necessary to perform microsurgeries in order to remove sperm from the testicle ${ }^{39}$.

\section{Enhancement of seminal quality}

Even though there are therapeutic possibilities to obtain sperm samples, the low sperm quality remains the main factor responsible for infertility in SCl patients. The management of this condition requires high technology artificial insemination methods, characterized by ovule intracytoplasmatic injection of spermatozoa ${ }^{5}$.

However, even with all these therapeutic options, some couples fail in the attempt to form offspring biologically. In these cases, they can use sperm obtained from a sperm bank or the couple is advised to think about adoption.

\section{FINAL CONSIDERATIONS}

$\mathrm{SCl}$ is a pathology with elevated morbidity for patients who survive trauma. Besides motor and sensitive impairments, the neurological deficit implies disability of many other biological systems, including the reproductive system. The prevalence of erectile dysfunction in males after $\mathrm{SCl}$ is almost ten times greater than in the regular population, and this fact, associated with anejaculation and poor seminal quality, results in a high percentage of infertility.

The treatment for males with $\mathrm{SCl}$ depends on the capacity of the patient to achieve erection and ejaculation. For males unable to sustain an effective erection there are different therapies that may be imposed, including pills, injections, tablets and penile implant. However, many patients with adequate erection and even ejaculation remain infertile because seminal quality is low.

This fact is a consequence of the spinal cord damage, which impairs the medular reflex and cortical control over the reproductive apparatus involved in intercourse. Therefore a patient with low sperm quality requires specialized methods in order to obtain offspring, such as insemination methods in human reproduction clinics.

According to this concept hyperbaric oxygenation therapy is a promising therapeutic goal that is still being studied. High oxygen tension in injured tissues promotes collagen synthesis, angiogenesis and local epithelization, events that are essential to neuronal and testicular repair, diminishing the involvement of the reproductive system and, consequently, infertility rates.

\section{ACKNOWLEDGEMENTS}

Financial support: AOSpine Latin America.

\section{REFERENCES}

1. National Center for injury prevention and control. [cited 2012 31/08/2012]; Available from: http://www.cdc.gov/ncipc/dactsheets/scifacts.htm.

2. Hansebout RR, Kachur E. Acute traumatic spinal cord injury. In: Wilterdink JL, editor. Uptodate. Waltham, USA: Uptodade; 2012.

3. Brackett NL, Ferrell SM, Aballa TC, Amador MJ, Lynne CM. Semen quality in spinal cord injured men: Does it progressively decline postinjury? Archives of physical medicine and rehabilitation. 1998:79(6):625-8.

4. Iremashvili V, Brackett NL, Ibrahim E, Aballa TC, Lynne CM. Semen Quality Remains Stable During the Chronic Phase of Spinal Cord Injury: A Longitudinal Study. The Journal of Urology 2010:184(5):2073-7.

5. Iremashvili V, Brackett NL, Ibrahim E, Aballa TC, Lynne CM. A Minority of Men With Spinal Cord Injury Have Normal Semen Quality-Can We Learn From Them? A Case-control Study. Urology. 2010:76(2):347-51.

6. Rodrigues D, Herrera G. Recursos fisioterapêuticos na prevenção da perda da densidade mineral óssea com lesão medular. Acta Ortopédica Brasileira. 2004 jul/set;12(3):183-8.

7. Falavigna A, Righesso Neto O, Ferraz FA, Boniatti MM. Traumatic fracture of the thoracic spine T1-T10. Arq Neuropsiquiatr. 2004 Dec;62(4):1095-9.

8. Falavigna A, Righesso Neto O, Polesso MA, Franceschini PR. Anterior approach in patients with traumatic compression fracture type of thoracolumbar spine (T11-L2). Arq Neuropsiquiatr. 2007 Sep;65(3B):906-11.

9. Durga A, Sepahpanah F, Regozzi M, Hastings J, Crane DA. Prevalence of Testosterone Deficiency After Spinal Cord Injury. PM\&amp;R. 2011;3(10):929-32.

10. Kafetsoulis A, Brackett NL, Ibrahim E, Attia GR, Lynne CM. Current trends in the treatment of infertility in men with spinal cord injury. Fertil Steril. 2006 Oct;86(4):781-9.

11. Kathiresan ASO, Ibrahim E, Aballa TC, Attia GR, Lynne CM, Brackett NL. Pregnancy outcomes by intravaginal and intrauterine insemination in 82 couples with male factor infertility due to spinal cord injuries. Fertility and Sterility. 2011:96(2):328-31.

12. Huang G, Gronthos S, Shi S. Mesenchymal stem cells derived from dental tissues vs. those from other sources: their biology and role in regenerative medicine. Journal of Dental Research. 2009;88(9):792-806.

13. Krausz C. Male infertility: Pathogenesis and clinical diagnosis. Best Practice \&amp; Research Clinical Endocrinology \&amp; Metabolism. 2011;25(2):271-85.

14. Monga M, Bernie J, Rajasekaran M. Male infertility and erectile dysfunction in spinal cord injury: A review. Archives of physical medicine and rehabilitation. 1999;80(10):1331-9.

15. Kaminski E. Transplante de células mononucleares da medula óssea em um modelo experimental de lesão da medula espinhal [tese]. Porto Alegre: Pontificia Universidade Católica do Rio Grande do Sul; 2011.

16. Falavigna A, Teles AR, Velho MC, Kleber FD. Effects of hyperbaric oxygen therapy after spinal cord injury: systematic review. Coluna/Columna. 2009;8:330-6.

17. LinsenmeyerTA, Perkash I. Infertility in men with spinal cord injury. Arch Phys Med Rehabil 1991;72:747-54

18. Tuzgen S, Kaynar M, Guner A, Gumustas K, Belce A, Etus V, et al. The effect of epidural cooling on lipid peroxidation after experimental spinal cord injury. Spinal Cord. 1988:36:654-7.

19. Tator $C$, Fehlings M. Review of the secondary injury theory of acute spinal cord trauma with emphasis on vascular mechanisms. J Neurosurg 1991;75:15-26.

20. Ricciardi R, Szabo CM, Poullos AY. Sexuality and Spinal Cord Injury. Nursing Clinics of North America. 2007:42(4):675-84

21. Safarinejad MR. Level of injury and hormone profiles in spinal cord-injured men. Urology. $2001 ; 58(5): 671-6$
22. Brackett NL, Ibrahim E, Iremashvili V, Aballa TC, Lynne CM. Treatment for Ejaculatory Dysfunction in Men With Spinal Cord Injury: An 18-Year Single Center Experience. The Journal of Urology. 2010:183(6):2304-8.

23. Kathiresan AS, Ibrahim E, Aballa TC, Attia GR, Ory SJ, Hoffman DI, et al. Comparison of in vitro fertilization/intracytoplasmic sperm injection outcomes in male factor infertility patients with and without spinal cord injuries. Fertil Steril. 2011 Sep:96(3):562-6.

24. Ibrahim E, Brackett NL, Aballa TC, Lynne CM. Safety of a novel treatment to improve sperm motility in men with spinal cord injury. Fertility and Sterility. 2009;91(4, Supplement):1411-3.

25. Pasqualotto FF, Sharma RK, Kobayashi H, Nelson DR, Thomas Jr AJ, Agarwal A. Oxidative stress in normospermic men undergoing infertility evaluation. J Androl. 2001 Mar-Apr:22(2):316-22.

26. Pasqualotto FF, Umezu FM, Salvador M, Borges E, Sobreiro BP, Pasqualotto EB. Effect of cigarette smoking on antioxidant levels and presence of leukocytospermia in infertile men: a prospective study. Fertility and Sterility. 2008:90(2):278-83.

27. Pasqualotto FF, Sundaram A, Sharma RK, Borges Jr E, Pasqualotto EB, Agarwal A. Semen quality and oxidative stress scores in fertile and infertile patients with varicocele. Fertil Steril. 2008 Mar;89(3):602-7.

28. Sharma RK, Agarwal A. Role of reactive oxygen species in male infertility. Urology. 1996 Dec;48(6):835-50.

29. Agarwal A, Saleh RA. Role of oxidants in male infertility: rationale, significance, and treatment. Urol Clin North Am. 2002 Nov:29(4):817-27.

30. Kodama H, Yamaguchi R, Fukuda J, Kasai H, Tanaka T. Increased oxidative deoxyribonucleic acid damage in the spermatozoa of infertile male patients. Fertil Steril. 1997 Sep;68(3):519-24.

31. Wang X, Sharma RK, Gupta A, George V, Thomas AJ, Falcone T, et al. Alterations in mitochondria membrane potential and oxidative stress in infertile men: a prospective observational study. Fertil Steril. 2003 Sep;80 Suppl 2:844-50

32. Brackett N. Semen retrieval by penile vibratory stimulation in men spinal with spinal Cord injury. Human Reproduction Update. 1999 May 1;5(3):216-22.

33. Padron OF, Brackett NL, Sharma RK, Lynne CM, Thomas AJJ, Agarwal A. Seminal reactive oxygen species and sperm motility and morphology in men with spinal cord injury. Fertil Steril. 1997 Jun;67(6):1115-20.

34. Aitken RJ, Krausz C. Oxidative stress, DNA damage and the Y chromosome. Reproduction. 2001 Oct;122(4):497-506.

35. Agarwal A, Said TM. Role of sperm chromatin abnormalities and DNA damage in male infertility. Hum Reprod Update. 2003 Jul-Aug;9(4):331-45.

36. Griveau JF, Dumont E, Renard P, Callegari JP, Le Lannou D. Reactive oxygen species, lipid peroxidation and enzymatic defence systems in human spermatozoa. J Reprod Fertil. 1995 Jan;103(1):17-26.

37. Moustafa MH, Sharma RK, Thornton J, Mascha E, Abdel-Hafez MA, Thomas AJJ, et al. Relationship between ROS production, apoptosis and DNA denaturation in spermatozoa from patients examined for infertility. Hum Reprod. 2004 Jan;19(1):129-38

38. Hillard V, Peng H, Das K, Murali R, Moorthy C, Etlinger J, et al. Inhibition of x-irradiation-enhanced locomotor recovery after spinal cord injury by hyperbaric oxygen or the antioxidant nitroxide tempol. Journal Neurosurgy Spine. 2007:6(4):337-43.

39. Maddox S. Paralysis Resource Guide. 2 ed. Short Hills, New Jersey: Christopher and Dana Reeve Foundation; 2011 